\title{
Holistic Information Support For Virtual Business Organization ${ }^{1}$
}

Vojko Potocan ${ }^{2}$, (E-mail: vojko.potocan@uni-mb.si), University of Maribor, Slovenia

\begin{abstract}
Assessing and implementing a virtual organizational provides an organization a template for increasing the control and viability of its operations. Under circumstances of restricted availability of factors and presently restrictive conditions of business operation, results can be improved by adequate information support for business operation. Various solutions are available to improve information support quality, while a primer example of important improvement of business is provided by a holistic information support of business, its management and basic processes. The business process is based upon the information basis with which we represent important characteristics of the examined field and the requisite additional knowledge (from both the content and methodological aspects). Holistic information support for business by means of a virtual organization presents an important viewpoint of its consideration, which, to a great extent, determines the quality of the entire business, and it also has a major impact on the results of business operation.
\end{abstract}

\section{THE SELECTED PROBLEM AND VIEWPOINT OF THIS CONTRIBUTION}

$T$

he hyper-competitive global economy has created a new competitive landscape - one in which events change constantly and unpredictably (Ireland, Hitt, 1997; Galbraith, 2003; Daft, 2003). The conditions of globalization require companies to transform from the traditional industrial enterprises into the modern postindustrial ones, which are more open, flexible and innovative.

Trends that appeared together with the development and the increasing application of information technology, and whose influence on the organization structure is the greatest, are: business globalization, change in the employment structure, elimination of boundaries between the parts within the organizations, but also between individual organizations.

Many organizations form strategic relationships in order to compete effectively (Porter, 1985, 1990). Many of these strategic relationships are conceived as a means to increase both the efficiency and effectiveness of those involved in these strategic relationships (Williamson, 1991; Gundlach, Achool, Mentzer, 1995; Galbraith, 2002; Daft, 2003). Inter-organizational relationships have become one of the most frequently used means of entering or expanding in the global marketplace (Varadarajin, Cunningham, 1995).

The virtual organization concept is a specific case of such relationships.

Virtual organizations enable organizational and/or individual core competencies to be brought together when needed, and disbanded when no longer required on one hand. On the other hand, competitive pressure over the modern conditions of business requires a high quality of business functioning. Business functioning of virtual organizations can be significantly improved mainly in the field of its management, which is its least developed and investigated area. A holistic information support to management presents an important viewpoint of management, which, to a great extent, determines the quality of the entire functioning of management and has also a major impact on the results of the business operation. These are true in general and even more so for the virtual organizations.

\footnotetext{
${ }^{1}$ The previous version was published in Proceeding of 2004 International Applied Business Research Conference, held in Puerto Vallarta, Mexico, March 14-18, 2005.

${ }^{2}$ Dr. Vojko POTOCAN, associate professor of organization and management.
} 
In this contribution we shall, therefore, focus on the consideration of the virtual business organization concept, provision of information support for a virtual organization, and creation of holistically information support to the virtual organization.

\section{THE VIRTUAL BUSINESS ORGANIZATION CONCEPT}

A distinguishing feature of the $21^{\text {st }}$ century is the prevailing and pervasiveness of different types and forms of networks, whether digital, social or organizational. The term "network", both a noun and a verb, is one of the most widely used words in our everyday vocabulary. (See: Webster, 1978; Black, 1997)

A virtual business organization is "a collection of business units in which people and work processes from representing in the business units interact intensively in order to perform work, which benefits all" (See: Porter, 1985; Porter, 1990). Although virtual business organizations have become a relatively widespread business approach to structuring business, the underlying concepts of linking competencies across business units or organizations have been in existence for some time earlier, too. These business linkages enable organizations to coordinate the transactions and activities more tightly across a value chain. Virtual reality, virtual space, virtual organizations, virtual teams: "virtual" is today's organizational buzzword (Johansson, 1995; Black, 1997; Potocan, 1997; Potocan, 2002; Galbraith, 2002; Daft, 2003; Cole, 2004; Warner, Witzel, 2004).

Virtual organizations, as we have said above, enable organizational and/or individual core competencies to be brought together when needed, and disbanded when no longer required (See: Williamson, 1991; Varadarajin, Cunningham, 1995; Becker, Kugeler, Rosemann, 2000; Harmon, 2003). These new firms mirror the fluidity of the global markets, creating and disbanding resources as dictated by the marketplace. Global location, and technical-, workforce- and market expertise advantages can be heightened through the use of a virtual organizational structure (Davidow, Malone, 1995; Daft, 2003; Cole, 2004; Warner, Witzel, 2004).

The rationale for forming a virtual business organization varies for the different entities involved in each relationship (See: Speier, Harvey, Palmer, 1998; Harvey, Speier, Novicevic, 2000; Galbraith, 2002). The desire to excel in a market characterized by hyper-competition, has motivated a growing number of organizations and individuals to search for uncommon associations to help develop creative and perhaps more effective strategies. Virtual organizations are able to generate new products more quickly, decrease the risk of pursuing a new opportunity, increase the visible organizational size, and decrease cycle times by relying on synergies of the core competencies of all their membership (See: Black, Edwards, 2000). Characteristics of virtual organizations evolve continuously. However, some characteristics have been identified and include (Porter, 1985; Porter, 1990):

- A web of companies, each contributing resources,

- Virtually vertically integrated,

- $\quad$ Linked through inter-enterprise business and production systems,

- $\quad$ Aimed at reduced business cycle time, and

- $\quad$ Aimed at one-stop shopping.

It would appear that creating a virtual organization to generate a product or service more effectively could include these two forms: removing inefficient transaction costs from the value chain, such as reducing time to market, and enhancing the overall value of the product or service by adding value to existing activities in the value chain.

The tactical and operational activities are left to member units; at least in the models we have detected (Potocan, 2002). Virtual global strategic organizations involve inter-organizational relationships that exist in a variety of forms. These relationships can be based on existing relationships between firms and often reflect prior competitive or cooperative interactions (See: Hill, Hitt, Hoskisson, 1992; Gundlach, Achool, Mentzer, 1995; Allcorn, 1997; Ireland, Hitt, 1997; Galbraith, 2002; Daft, 2003; Harmon, 2003; McShane, Von Glinow, 2004). In addition to these inter-organizational strategic relationships, firms must have an economic incentive for participation. Strategic needs, desire for performance enhancements, or an attempt to foster innovation can drive these incentives. Nike, e.g., was 
one of the first organizations that took advantage of advanced communication and logistic technology to create a global network of organizations to produce athletic shoes instead of keeping all the work inside the organization (Snow, Miles, Coleman, 1992; Potocan, 1997; Potocan, 2002; Potocan, Mulej, 2004)

Five models of virtual global strategic organizations begin to emerge from the existing literature (See: Porter, 1990; Davidow, Malone, 1993; Rayport, Sviokla, 1995; Allcorn, 1997; Glabraith, 2002; Daft, 2003; Potocan, Mulej, 2004). They are:

- $\quad$ Shared Partnership (e.g. Microsoft's alliance with Lego; General Electric and Eastman Chemical; IBM, Sun, and Hewlett Packard on the development of the Internet programming language JAVA) (See: Dess et al., 1995),

- $\quad$ Core/Satellite (See: Chraysler/Daimler Benz; Pliva biotechnology Company, etc.) (See: Harrigan, 1988; Anderson, Narus, 1990; Snow, Miles, Coleman, 1992),

- Virtual Value Chain (e.g. IBM, Wal-Mart, Benetton, etc.) (See: Ring, Van De Ven, 1992),

- $\quad$ Integrated Firm (e.g.: BASF, etc.) (See: Anderson, Hakasson, Johnson, 1994),

- $\quad$ Electronic Market (e.g. World Wide Web, amazon.com, Royal Bank of Scotland) (See: Bakos, 1991, Rayport, Sviokla, 1995; Oates, 1998).

The mentioned models share common elements of coordination through (1) the use of information technologies, and (2) communication technologies, and (3) the performance of work across time and space (See: Snow, Miles, Coleman, 1992; Gunton, 1998; Lucey, 1998; Speier, Harvey, Palmer, 1998; Harvey, Speier, Novicevic, 2000; Galbraith, 2002; Morgan, 2002; Grant, 2003; Harmon, 2003; Potocan, 2004a).

All five models address the basic process, primarily or even exclusively. The management and the information processes are obviously left aside (See: Galbraith, 2002; Daft, 2003; Potocan, Mulej, 2003; Potocan, Mulej, 2004). In the reality, as visualized by business cybernetics (See: Checkland, Holwell, 1998; Mulej, Kajzer, 1998), this is a case of a crucial lack for the creation of requisite holism. That's why we will add the information viewpoint, although on the level of a first discussion, only.

\section{INFORMATION SUPPORT FOR VIRTUAL ORGANIZATIONS}

\section{The Usual Information Systems For Virtual Organizations}

The spread of information technology supporting the virtual organization model varies, ranging from simple communication technology such as e-mail, fax and teleconferencing to groupware, videoconferencing and interorganizational linkages such as EDI (See: Goldman et al., 1995; Davidow, Malone, 1995; Palmer, 1998; Morgan, 2002; Grant, 2003; Warner, Witzel, 2004). All the services mentioned are Internet services. Where and when a virtual organization applies a distinct information technology and employs an information system, the design depends on the content and on the characteristics of co-operation.

The business process of a virtual organization is organized, according to models, so as to serve a basis for workflow between partners. A comprehensive and sustainable model for all co-operation processes is difficult to construct. The problem has, to some extent should be founded on those more stable structures in the co-operation processes. The most structured and frequently recurring processes are called pre-determined processes. Unique and flexible processes, which are un-structured, are called ad-hoc processes. Processes in between these extremes are referred to as semi-structured processes. Each process type within a virtual organization requires a different information and communication system.

Unstructured and semi-structured processes offer limited possibilities for workflow automation. Less structured co-operation processes can be supported, if one supplies employees with an assorted set of diverse communication media, each consisting of certain functionalities. The most suitable for these types of processes are the information and communication systems, which are based on technologies for computer supported co-operative work $(\mathrm{CSCW})$. Approaching this situation, a virtual organization has first to develop a layer framework, which provides a 
description of the relationship between co-ordination and co-operation processes, the underlying human communication processes, and the communication media (See: Englert et al., 1996). Then a document-based information system can be developed if one uses groupware technology (e.g. Lotus Notes). Such information systems should provide the user with a toolbox, which contains a sufficiently extensive set of communication media to deal with each specific context.

On the other hand, structured and predetermined processes require workflow automation and interorganizational information and communication systems, which support data exchange between information systems of partners in the virtual organization (See: Goldman at al., 1995; Davidow, Malone, 1995; Morgan, 2002; Harmon, 2003). A workflow information system is under control of the responsible person with relevant support and the necessary data at the appropriate point in the process. These systems also allow organizations to dynamically define, execute, manage, and modify business processes. The workflow information system controls the process flow. It provides the screen forms needed for data to be input and output at every step in the process. Workflow information systems are suited to well-structured processes, where clearly-defined rules determine the execution order of the process steps.

In the last few years, however, we have seen a growing tendency towards package-ware. Information and communication systems in areas such as sales and marketing, production and procurement, are supported by enterprise resource planning (ERP) solutions. The ERP systems automate generic versions of the business process, often internally using a workflow engine for process customization, control and automation. In recent years we have also seen a growing tendency towards seamless integration of business processes in virtual organizations. Information technology and the Internet play a crucial role here. Global companies use the Intranet or Extranet to communicate internally using Internet technologies. But the integration of business processes does not stop at company boundaries. Supply chain processes are integrated using web and other e-commerce technologies from the supplier all the way through the producer to the consumer (See: Palmer, 1998; Gloor, 2000; McDonald, 2000; Morgan, 2002; Grant, 2003). To link business processes in virtual organizations, the underlying information systems needs the capability to link information seamlessly and automatically.

\section{Enterprise Resource Planning (Erp) Solutions In Virtual Organizations}

ERP solutions provide support in areas such as accounting and controlling, production and material management, quality management and plant maintenance, sales and marketing, project management, and human resources. Leading vendors of ERP solutions for large companies are SAP, Oracle, Baan, etc. SAP is by far the largest ERP vendor (See: Palmer, 1998; McDonald, 2000; Gloor, 2000; Morgan, 2002; Grant, 2003; Warner, Witzel, 2004). With its MySAP.com initiative, it is moving quickly into the e-business area, combining SAP standard business applications with standard Internet technologies. ERP and e-business integration defines new information systems architecture for virtual organizations, which can be described as ERP based e-business.

ERP based E-business improves business performance by using information technologies and open standards to connect suppliers, partners and customers at all steps along the value chain. These information systems can significantly improve business performance by strengthening the linkages in the value chain between businesses, and between a business and its ultimate customer. Streamlining of business processes in virtual organizations involves three imperatives:

\footnotetext{
- $\quad$ trust among business partners,

- agreement on standard ways of working,

- $\quad$ agreement on common data exchange standards that facilitates dialogue on mutual business events over the Internet.
}

This applies to virtual organizations, too. Why? 
Different authors (See: Oesterle, Fleisch, Alt, 2000; Morgan, 2002; Harmon, 2003, Potocan, Mulej, 2004; Warner, Witzel, 2004) suggest a model that reflects major principles of the networked enterprise - the virtual organization. The four building blocks of the model are:

- $\quad$ Networked processes - e-business enables direct co-operation between partners and core organization processes

- $\quad$ Business bus - e-business enables co-operation between partners based on a high level of standardization

- $\quad$ Electronic services - e-business enables co-operation with externalized services

- $\quad$ Service integrator - e-business enables co-operation with new players - "infomediaries" - within business networking.

All these processes / blocks are linked into one entity by information. They require resources. In order to make rational decisions about how to deploy resources in implementing ERP-based e-business, a virtual company must know both its starting position in the e-business panorama and its desired end state, related to the various possibilities. The ERP/e-business matrix (See: Noris et al., 2000; Morgan, 2002; Grant, 2003) defines four scenarios for an ERP based e-business:

- $\quad$ Channel enhancement - modifying existing business processes

- Value-chain integration - integrating suppliers, partners and customers through e-business customer relationship management (eCRM) and through e-business supply chain management (eSCM)

- $\quad$ Industry transformation - restructuring virtual organization

- $\quad$ Convergence - partnering with companies from different industries.

ERP based e-business information systems require extended ERP functionality. In the e-world, the focus is no longer just on how well an ERP system can store and manage data and move it around within the company. It rather has to engage in adding value to that data in order to turn it into information, knowledge, and initiating a requisitely holistically grounded action, and moving that data and information across a virtual organization to create knowledgeable and well performing extended organizations. Some areas in which ERP systems are likely to expanded are:

- Web based customer relationship management (eCRM), which has to support e-commerce and data mining

- $\quad$ Advanced planning and scheduling, which has to provide a better way of managing information flow connected with manufacture resource planning

- $\quad$ Web based supply chain management (eSCM)

- Value based strategic management of virtual organization (e.g. virtual organization sales plan, build plan, etc)

- $\quad$ Shared services in the way of creating virtual shared service centers (SSC) in virtual organization.

The major benefit of ERP based e-business information systems will be realized when production planning and procurement of all materials - production and non-production - together with selling and buying are web-enabled and integrated.

Even if this demand is satisfied, although this is no easy task, at least one more essential issue shows up: Does the information system supply adequate data, messages and information? It is at this point that the concept of holistic information and communication support to the virtual organization may be helpfully applied.

\section{HOW TO CREATE HOLISTIC INFORMATION SUPPORT TO A VIRTUAL ORGANIZATION}

\section{Business Operation Of Virtual Organizations And The Requisite Holism Of Information}

The economic operations present the major field of business, which in turn is based on various sorts and types of information (quantitative, qualitative) (See: Laudon, Laudon, 1998; Fry, Stoner, 2000; Morgan, 2002; Harmon, 2003). For the adequate running of a business operation are necessary all requisite (system of) various information with which quantity, value and quality (or any other important operational characteristics) are measured. 
However, their treatment is linked to the variety of content and methodology choices (See: Brittan, 1997; Gunton, 1998; Fry, Stoner, 2000; Warner, Witzel, 2004). In addition, their treatment is linked to a number of various issues concerning both its content and methodology. A requisite holism (See: Mulej, Kajzer, 1998; Rebernik, Mulej, 2000) of the treatment can best be attained if a dialectical rather than a complete (total) system of viewpoints is applied; the too often chosen single viewpoint does not provide the requisite holism either (See: Modis, 1998; Mulej et al, 2000, and earlier from 1974).

The research about and the development of, the information support to business operation involves (1) the development of a (requisitely) holistic methodology of information support, and (2) creation of (requisitely) holistic implementation of information support. The created support system of information processes to business also determines the starting points for a possible choice of the theoretical starting points in related sciences (economics, business) for meaningful support of the business. A complex methodology is required for retrieval and presentation of information based on the business sciences. This is especially true in the case of their systemic (requisitely holistic) treatment.

If the Mulej/Kajzer law of requisite holism is closely considered, the approach to and the process of making and using the system of information will provide support to business (Mulej, Kajzer, 1998). A lack of consideration of the Mulej/Kajzer law of requisite holism may rather easily become apparent if the decision makers and their support offices / assistants try to limit the scope of their efforts to a single viewpoint and/or to hard-systemic data alone, such as accountancy or over-quantified marketing research data. They should rather use a soft systems approach, too, and hence draw on different data and judgments (see: Checkland, Holwell, 1998).

This statement may be well understood, in general, but there may be still an open issue of how can the requisite holism of information can be attained in the virtual organizations. We shall, therefore, next focus on the discussion of some issues concerning to: (1) information support to a virtual organization from the perspectives of the soft systems theories, information support and law of requisite holism, and (2) the new ethics (e.g. ethics of interdependence) for information support to virtual organization (and virtual organization in general).

\section{Information Support to a Virtual Organization from the Perspectives of the Soft Systems Theories}

Due to the above conclusion, we deal with the business operation of a virtual organization from the viewpoints of information as a part of the objective starting points; inside them we consider possibilities/sources rather than needs, which can be met with them. Information represents important (=requisitely holistically presented) characteristics of the examined field and the requisite additional knowledge (from the content and methodological aspects) (See: Laudon, Laudon, 1998; Becker, Kugeler, Rosemann, 2000, Potocan, Mulej, 2004). The development of the information support to organization operation enables the acquisition of both non-economic and general economic information as a picture/model of business operation from the (dialectical system of) selected viewpoints (See: Mulej, 1974; Borghoff, Pareschi, 1998; Flood, 1999; Mulej et al., 2000).

The business operation can be considered adequate when it takes place successfully (efficiently and effectively in economic terms), is respected (from the aspect of business behavior) and ethical (morally adequate from the aspect of a responsible attitude towards the social and natural environment) (See: Gunton, 1998; Flood, 1999). The business operation needs different kinds of information that can, broadly, be defined as general information (See: Potocan, 1997; Potocan, 2001; Potocan, Mulej, 2003; Potocan, Mulej, 2004). The major part of general information can also have a direct or indirect impact on the economics of the business. For this reason, the information - business related - can also be defined as the economic information in the broadest sense of the word. In the business treatment, we can also encounter a group of information that can be defined as non-economic information (complementary to the economic information in the work process). These are the messages, data or information that are indirectly related to the business or not included (and/or not applied) in the treatment of business, such as sociology, psychology, communication, technology development, languages, etc.

The problem of the theory and practice of business informatics, since its beginning, has erred in its target orientation to ensure the acquisition of direct economic/business information (See: Gunton, 1998; Lucey, 1998; 
Becker, Kugeler, Rosemann, 2000; Fry, Stoner, 2000; Morgan, 2002; Grant, 2003). Information support has very often been limited only to the financial aspect of the economic/business operation. Financial information presents, nevertheless, an important subsystem of information and is, at the same time, rarely a partial system of the required complete information support to business operation (it is too often considered a subsystem, rather than a partial system). Modern business information focuses on providing most of the information necessary for the business operation. Herein is to be found the increased importance of another subsystem of information, which tackles not only economics in its content, but has however a big (indirect or direct) impact on the economics of the business. Owing to its significance and impact on the economics of business, we have defined this information as the (direct) economics information. The non-economic information is complementary to it; these two types of information together meet the law of the requisite holism together.

The treatment of the indirect economic information is difficult and is additionally made more difficult by the problems of its definition (See: Potocan, Kajzer, Mulej, 1997; Potocan, 2001; Potocan, 2002; Potocan, Mulej, 2003; Potocan, Mulej, 2004). At the level of its content definition, the information can be defined as objective and/or subjective. The objective information is the information that exists outside humans and can be rather well defined and, therefore, well investigated on the basis of different quantitative units of measure (i.e.: quantity, weight, value). On the other hand, we have subjective information that is less unified and less clearly defined. The subjective information is, as a rule, examined by the application of various quality units or even only by the application of descriptive criteria. Objective and subjective messages, data, and information require interpretation, which tends to be quite subjective, because humans do it. However, we have not yet exhausted the problems of how to define the objectivity and subjectivity of information, which can further be dealt with on the basis of the needs and the definition of the requisite objectivity. In the literature to which we have access, we do not encounter investigations that thoroughly study the issues of the subjective information and/or the subjectivity of the information definition.

A needed information structure for running the business presents an additional problem as it concerns the treatment of the business information support (See: Potocan, Kajzer, Mulej, 1997; Potocan, Mulej, 2003; Potocan, Mulej, 2004). In this, we encounter two aspects of the structure suitability, namely: adequately targeted information, and a suitable level of unification of information. For the needs of the individual business (of different kind, type and form) and business operations in the individual areas of industries and markets, we need the information that is suitably conceived and created in accordance with the set goals. On the other hand, we need different general and specific information for each business operation.

If we want to define holistic information support of business operations, we must first define the level of research, creation and application of information support. The Law of requisite holism presents one possible solution for that.

\section{Information Support and Law of Requisite Holism}

A central question in the creation of information support to business rests in the definition of its basic characteristics (how do we define the level of its holism, variety, effectiveness, efficiency, entanglement, simplicity, unification, standardization, originality, etc.) (See: Potocan, 1997; Potocan, Kajzer, Mulej, 1997; Merry, 1999; Merry, 2000; Morgan, 2002; Grant, 2003; Harmon, 2003; Cole, 2004; Potocan, Mulej, 2004; Warner, Witzel, 2004). It all depends on our selection of the individual viewpoint / dialectical system / viewpoints system / total system of viewpoints (Mulej et al., 2000; Potocan, 2002).

In the treatment of business phenomena, we additionally encounter the problems of how to define a requisite information support for business operation (Potocan, Kajzer, and Mulej, 1997; Mulej et al., 2000; Potocan, Mulej, 2003). A necessary support in our view can be defined as the state of consideration of the phenomenon that enables us to create a requisitely holistic insight into the phenomenon and a requisitely good quality of treatment of business. On the other hand, the requisitely holistic support can be defined as the state of the insight in the phenomenon, which enables us to create a requisitely usefully picture of the phenomenon in accordance with the starting points of the treatment. Holism can be delimited likewise. The sufficient level of holism is, therefore, frequently lower than the necessary one (Mulej, Kajzer, 1998; Mulej et al., 2000). These two levels together mostly attain the requisitely level, anyway. 
The above findings, additionally confirm the fact that the examination of business operation is very demanding. This especially applies to the information support of business operation. An appropriate level of information support for business operation can be defined according to the law of the requisite holism. We apply this law to the treatment of entanglement of information support.

Mulej and Kajzer formulated the Law of requisite holism in 1998 (Mulej, Kajzer, 1998; Mulej et al., 2000). It is defined at a very minimum by the following characteristics. The entanglement of the nature has constantly been increasing. Its complicatedness relates to attributes of single components alone, its complicatedness results also from their interactions, which are mostly based on their interdependencies, mostly. New features and new insights are constantly added. The increase of complexity of life is thus quicker than the adaptation of the human abilities to understand and manage it holistically (See: Mulej, Kajzer, 1998; Flood, 1999; Potocan, 2000; Potocan, 2001). Humankind has been intensifying many narrow specializations and is, therefore, restricted to the individually selected aspects and to the individually selected phenomena. The systems theory endeavors to assert the holism of the examined reality, of the life and its components. Each author, within the definition of their starting points for the treatment, defines what they see as a requisite holism in their case.

The Mulej/Kajzer law expresses the difficulties, which are results of the entangled reality. Within an enhanced, deeper investigation we can see that it makes sense to study the entanglement concepts in more detail in order not to miss anything very important. On the basis of the mentioned cognitions we research the selected starting points of the economic examination of business. The Mulej/Kajzer law of the requisite holism applies to the comprehensiveness of thinking, decision-making, and action.

On the other hand, the Ashby's Law of requisite variety (Ashby, 1973) mainly advocates the fact that each unit / entity / system must, after its appearance, care for the maintenance (and an appropriate development) of its identity in order to have (in an ideal case) an adequate response prepared in advance for each and every important impact from the environment, threatening its identity.

The requisite holism of the information support may best be attained if both the Mulej/Kajzer and the Ashby laws are adhered to. This applies to both the traditional and the virtual organization, but may be a lot more complex and complicated in the case of the virtual one, because its legal and management frameworks are more fluid. There is a further set of laws using the attribute requisite (Bausch, 2003).

The introduction of the idea of holistic information support for virtual business organization's management requires all its participants to reconsider and restructure their behavior (e.g. their ethics) at all levels and in all areas of their activities. In other words, we need new ethics, if we wish to create a new way of thinking and a new style of working and appropriate behavior in virtual organization (See: Potocan, 2000; Rebernik, Mulej, 2000).

\section{New Ethics (e.g. Ethics of Interdependence) as a Precondition for Virtual Organization}

But what is ethics? In general terms ethics enables us to distinguish right from wrong (See: Sruk, 1986; Singer, 1993; Lunati, 1997; etc.). Empirical researchers consider ethics as a synergy of behaviors, which tend to be preferred in a society or community, as a social group, for long enough periods of time to come to be somewhat codified (See: Singer, 1993; Wilson 1998; McShane, Von Glinow, 2004).

\begin{tabular}{|l|c|c|}
\hline Individual values & $\rightarrow$ & Culture of a group sharing the prevailing values \\
\hline \multicolumn{1}{|c|}{$\uparrow$} & & $\downarrow$ \\
\hline Norms \& rules reflecting ethics & $\leftarrow$ & Ethics on what is right and wrong behavior \\
\hline
\end{tabular}

Moral and legal rules co-create acceptable values, ethics and a culture, be it for social sub-groups, for organizational units, for entire organizations, or groupings of regions, nations, social classes, professions. Thus, something, which is originally an individual attribute, comes to be objectified as a component of the objective conditions (i.e. external to single individuals). It becomes a part of broader requirements imposed on the individuals, and tends to return, in this way, back to individuals, as a part of their values, i.e. their emotional perception of the 
objective needs or requirements they face. Thus it enters (or re-enters) the individual's starting points, and their reentry influences perception, definition of preferences, their realization in the form of goals, and later on as tasks, procedures for realizing the tasks etc. It means that for any human activity ethics is equally as essential as professional knowledge and skills. We have in fact found all three (ethics, knowledge, skkils) to be mutually interdependent (See: Potocan, 2000; Rebernik, Mulej, 2000, Mulej et al., 2000; Potocan, Mulej, 2003; McShane, Von Glinow, 2004; Potocan, Mulej, 2004).

Modern ethics provide for reliability: partners can depend on fellow partners who behave ethically. In economic terms reliability has great value. It has not always been this way (Potocan, Mulej, 2003). Our own practical experience tends to confirm the observation made by Wilson (1998) saying that researchers find that the ethical norms have been changing in an evolutionary process based on the interplay of biological and cultural factors. This finding may hold true and explain many things, some of which may be quite relevant in the context of this contribution.

This development applies to creation and the usage of virtual organizations, as a modern step of development, as well. Ethics of interdependence is a necessary foundation for it. Why?

1. The virtual organizations are based on co-operation of legally independent, but economically interdependent organizations / entities, which network due to their shared interests and agreement (or contract) on a rather longer-term co-operation, rather than being bound together in a legal formalization. This fact is also the basis for the process of conceptualization and formation of their values / culture / ethics / norms. In addition, in a virtual organization ethics is impacted by the fact that there is a lack of legal means for regulation of the mutual relationship of its member organizations: a requisite of contemporary ethics - the ethic of mutual reliability - of all of them may be the main or even the only means left to establish a requisitely holistic functioning of and behavior in a virtual organization. Thus, the initiator-builders of a virtual organization invites only those organizations to co-operate with them that meet these two basic criteria at the same time:

(a) they are capable of performing the required activities within their competencies and with their endowments/assets, and

(b) they have demonstrated requisitely contemporary ethics in their recent history.

Hence, in the phase of constructing a virtual organization, ethics represents a decisive criterion for selection of potential participants and is based on the insight into their ethics of so far, reflecting trustworthiness.

2. Both the existence and the development of a virtual organization are based on a requisitely holistic understanding and implementation of the ethics of interdependence in its functioning and behavior. In economic terms, this diminishes its cost considerably, because mutual control is much less necessary, cooperation is much more based on mutual trust, agreements are hence attained more quickly, which may diminish time to market, etc.

(a) In the internal relation of a virtual organization, attainment of business results depends essentially on the co-ordination and fulfilling of the accepted obligations by its individual members. This makes the final outcome depend on the ethic of interdependence of all of them in the co-operation chain, supply chain, and profit chain. At the same time, one must take into account that obligations of every particular participating member are subject to his or her or their free will and agreement. A reliable partner functioning according to contemporary ethics standards. If these obligations are not met, the main penalty is the loss of trust in the unreliable partner by the other partners in the business environment because an indifferent parent lacks a basis of contemporary ethics for his functioning and behavior.

(b) On the other hand, the entire virtual organization also depends much on its own contemporary ethics, which is an indicative factor determining its role, importance, trustworthiness, creditworthiness, and public opinion in the market. Potential business partners prefer avoidance of the avoidable cost, including the cost of double-checking of a potential partner's trustworthiness, of course. A virtual organization is found less reliable, because it is made of a network of legally independent members that may in principle break up any time. Thus, a virtual organization's care for 
nurturing of the contemporary ethics in its relations to its customers and potential cooperators must be a lot more intense and requisitely holistic. Simply, it is judged and selected as a business partner on the basis of its public image as a very reliable one and this selection is much more stringent than in traditional organizations. The potential business partners react to any mistakes very quickly, which may be very painful for the virtual organization. Such an organization is, at the same time, much more vulnerable than the traditional one; it has less command over the assets. Thus, contemporary ethics makes a basic cornerstone for the formation of the image in a social and business environment of the modern kind, in which a total or even a systemic quality is required and comprises suitable cost, quality, range, uniqueness, and care for the natural and social environment.

Resulting questions include this one: where is the connection between ethics and the requisitely holistic formation of information and communication support for virtual organization. The role and importance of ethics depend on two basic things:

- How do we, first define, and then assure requisitely holistic information support for cognition, implementing and control of ethics of behavior, and

- How do we, first define, and then understanding ethics as a starting component and/or characteristics of the process of a requisitely holistic creation of information and communication support?

From the viewpoint under consideration - of a requisitely holistic information and communication support for virtual business organization - the contemporary ethics presents, along with knowledge and possibilities a source of requisitely holistic and there fore beneficial by helping the following to happen:

- Purpose and goal of formation of a requisitely holistic information in communication support,

- Starting points for the formation of a requisitely holistic information in communication support,

- Characteristics of formation, working and control of a requisitely holistic information in communication support, and

- An important result is the functioning and behaviour of a requisitely holistic information in communication support, which has influence (both forward and backward) assuring of information and communication support of the business organization.

\section{CONCLUDING REMARKS}

Virtual organizations enable organizational and/or individual core competencies to be brought together when needed, and disbanded when no longer required. Business operation of a virtual organization can be significantly improved mainly in the field of management. An important viewpoint of management is covered by the information support of its work on business, management of the business and basic processes.

The business process is based upon the information basis with which we represent important characteristics of the examined field and the requisite additional knowledge (from both the content and methodological aspects). The usual information system supporting the virtual organization varies, ranging from simple communication technology such as e-mail, fax and teleconferencing to groupware, videoconferencing and inter-organizational linkages such as EDI. Where and when a virtual organization applies a distinct information technology and information system, it depends on the content and on the characteristics of co-operation. Enterprise Resource Planning (ERP) Solutions in Virtual Organizations provide target oriented information support for different (and/or specific) functional areas of business.

But, does the above-mentioned process of creation of information support supply (assure) adequate and requisite data, messages and information for a virtual organization? The basic problem of the formation and of the application of examined information support is the requisite holism of the knowledge about the business situation and trends, about the object of business (content knowledge), about the methods (knowledge of methodology), and about the values, ethics and norms. 
Modern ethics is concerned with reliability, trustworthiness. This applies to virtual organizations to a high degree and requires a requisitely holistic information and communication support for decision-making and action. Some important starting points for its creations are: creation of information support on the basis of Soft Systems Theories, understanding and implementing of the Law of requisite holism for the definition of information and communication support, and use of ethics of interdependence for the creation of information and communication support to the virtual organization (and the functioning of virtual organization in general). These starting points supply a practical basis of reliability.

\section{REFERENCES}

1. Allcorn, S. (1997). Parallel Virtual Organizations - Managing and Working in the Virtual Workplace. Administration \& Society, 29(4), 412-439.

2. Anderson, J., Narus, J. (1990). A Model of Distributor Firm and Manufacturer Firm Working Partnership. Journal of Strategic Management, 54, 42-58.

3. Anderson, J., Hakasson, M., Johnson, J. (1994). Dynamic business relationships within a business network context. Journal of Strategic Management, 58, 1-15.

4. $\quad$ Ashby, R. (1973). An Introduction to Cybernetics. London: Chapman in Hall.

5. $\quad$ Bakos, J. Y. (1991). A Strategic Analysis of Electronic Marketplaces. MIS Quarterly, 15(3), 295-310.

6. Bausch, K. (2003). The Emerging Consensus in Social Systems Theory. New York: Kluwer.

7. $\quad$ Becker, J., Kugeler, M., Rosemann, N. (2000). Prozessmanagement. Heidelberg: Springer-Verlag.

8. Black, J. (1997). A Dictionary of Economics. Oxford: Oxford University Press.

9. Black, J., Edwards, S. (2000). Emergence of virtual or network organizations: Fad or feature. Journal of Organizational Change Management, 13(6), 567-576.

10. Borghoff, U., Pareschi, R. (1998). Information Technology for Knowledge Management. Berlin: Springer-Verlag.

11. Brittan, D. (1997). Business lessons from Darwin. MIT Reporter, 12(1), 12-13.

12. Checkland, P., Holwell, S. (1998). Information, Systems, and Information Systems. New York: Wiley \& Sons.

13. Cole, A. (2004). Management. London: Thomson.

14. Daft, R. (2003). Management. Mason: South-Western.

15. Davidow, H., Malone, S. (1995). The Virtual Corporation. New York: Harper Business.

16. Dess, G. (et al.) (1995). The New Corporate Architecture. Academy of Management Executive, 9(3), 7-17.

17. Englert J. (at al.) (1996). Beyond automation: A framework for supporting cooperation. In: Proceedings of $4^{\text {th }}$ European Conference on Information Systems. Lisbon: ECIS.

18. Flood, R. (1999). Rethinking the Fifth Discipline. London: Rootledge.

19. Fry, R., Stoner, C. (2000). Business: An Integrative Approach. Boston: McGraw Hill.

20. Galbraith, J. (2002). Designing Organizations. New York: Wiley \& Sons.

21. Gloor P. (2000). Making the E-business Transformation. Berlin: Springer Verlag.

22. Goldman, J. (et al.) (1995). Competitors and Virtual organizations. London: Van Nostrand Reinhold.

23. Grant, N. (ed.) (2003). E-business and ERP. New York: Wiley \& Sons.

24. Gundlach, G., Achool, R., Mentzer, J. (1995). The Structural Commitment in Exchange. Journal of Strategic Management, 59(4), 78-82.

25. Gunton, T. (1998). Infrastructure: Building a Framework for Corporate Information Handling. New York: Prentice Hall.

26. Harmon, P. (2003). Business Process Change. Amsterdam: Morgan Kaufmann Publishers.

27. Harrigan, K. (1988). Joint Ventures and Competitive Strategy. Strategic Management Journal, 9, 141-158.

28. Harvey, M., Speier, C., Novicevic, M. (2000). An Innovative Global Management Staffing System. Human Resource Management Journal, 39 (3).

29. Hill, C., Hitt, M., Hoskisson, R. (1992). Cooperative versus competitive structures in related and unrelated diversified firms. Organization Science, 3(4), 501-521.

30. Ireland, R., Hitt, M. (1997). Performance Strategies for high Growth Entrepreneurial Firms. Frontiers of Entrepreneurship Research, 9, 101-104.

31. Johansson, J. (1995). International alliances: Why Now? Journal of Academy of Marketing Science, 23(4), 301304.

32. Laudon, K., Laudon, J. (1998). Management Information Systems: A Contemporary Perspective. New York: McMillan Publishing.

33. Lucey, T. (1998). Management Information Systems. London: Letts Company. 
34. Lunati, T. (1997). Ethical Issues in Economics From Altruism to Co-operation to Equity. Houndsmills (UK): Macmillan Press.

35. McDonald, K. (ed.) (2000). Mastering the SAP Business Information Warehouse. New York: Wiley \& Sons.

36. McShane, S., Von Glinow, M. (2004). Organizational Behavior. New York: McGraw-Hill.

37. Merry, U. (1999). Nonlinear Organizational Dynamics. Http:// pw2.netcom.com / nmerry / art2.htm

38. Merry, U. (2000). Organizations Versus Natural Systems. Http:// www.tresholds.com / journal / articles / (marryone.htm-merrytwo.htm).

39. Modis, T. (1998): Conquering Uncerainty: Understanding Corporate Cycles and Positioning Your Company to Survive the Changing Environment. New York: McGraw-Hill.

40. Morgan, T. (2002). Business Rules and Information Systems. New York: Addison-Wesley.

41. Mulej, M. (1974). The Dialectical Systems Theory (In Slovenian). Ljubljana: University of Ljubljana, Faculty of Sports.

42. Mulej, M., Kajzer, S. (1998). Ethics of Interdependence and the Law of Requisite Holism. In: Rebernik, M., Mulej, M. (eds.): STIQE '98. Proceedings of the 4th International Conference on Linking Systems Thinking, Innovation, Quality, Entrepreneurship and Environment. Maribor: Institute for Systems Research.

43. Mulej, M. (et al.) (2000). Basics of Systems Theory. Maribor: Faculty of Economics and Business.

44. Noris G. (et al.) (2000). E-business and ERP: Transforming the Enterprise. New York: Wiley \& Sons.

45. Oates, D. (1998). Outsourcing and the Virtual Organization. New York: Barron-s Business Success Guide.

46. Oesterle H., Fleisch E., Alt R. (2000). Business Networking: Shaping Enterprise Relationships on the Internet. Berlin: Springer Verlag.

47. Palmer J. (1998). The Use of Information Technology in Virtual Organization. New York: Idea Group Publishing.

48. Porter, M. (1985). Competitive Advantage. New York: Free Press.

49. Porter, M. (1990). Competitive Advantage of Nations. New York: Free Press.

50. Potocan, V. (1997). Synergy and integration processes in business. Management, 2(2), 13-24.

51. Potocan, V., Kajzer, S., Mulej, M. (1997). The Standardization of the Methodological Basis of Business Decisionmaking as a Contribution to the Revival of the Systems Theory. Systemica, 1(6), 259 - 268.

52. Potocan, V. (2001). Synergies in a virtual company. Journal for Management and Development, 2(4), 45-60.

53. Potocan, V. (2002). Business Systems. Management, 7(2), 67-77.

54. Potocan, V., Mulej, M. (2003). On Requistely Holistic Understanding of Sustainable Development from Business Viewpoints. Systemic Practice and Action Research, 16(6), 421-436.

55. Potocan, V., Mulej, M. (2004). The requisite holism of information in a virtual business organization's management. The Journal of American Academy of Business, 5(1/2), 411-417.

56. Rayport, J. F., Sviokla, J. J. (1995). Exploiting the virtual value chain. Harvard Business Review, NovemberDecember, 75-85.

57. Rebernik, M., Mulej, M. (2000). Requisite holism, isolating mechanisms and entrepreneurship. Kybernetes, 29(9/10), $1126-1140$.

58. Ring, P., Van De Ven, A. (1992). Structuring Cooperative Relationships Between. Organizations. Strategic Management Journal, 13, 531-544.

59. Schultheis, R., Sumner, M. (1998). Management Information System. Boston: McGraw Hill.

60. Snow, C., Miles, R., Coleman, H. (1992). Managing $21^{\text {st }}$ Century Network Organizations. Organizational Dynamics, 20(3), 5-20.

61. Singer, P. (1999). Practical Ethics. Cambridge: Cambridge University Press.

62. Speier, C., Harvey, M., Palmer, J. (1998). Virtual Management of Global Marketing Relationships. Journal of World Business, 33 (3).

63. Sruk, V. (1986). Ethics and Moral (In Slovenian). Ljubljana: Cankarjeva zalozba.

64. Varadarajin, R., Cunningham, M. (1995). Strategic alliances: A synthesis of conceptual foundations. Journal of Academy of Marketing Science, 23(4), 282-296.

65. Warner, M., Witzel, M. (2004). Managingh in Virtual Organizations. London: Thomson.

66. Webster (1978). Webster's School and Office Dictionary. New York: Banner Press.

67. Wilson, O. (1998). Die Zehn Gebote Liegen in den Genen. Das biologische Fundament der Moral. Neue Zuercher Zeitung. Zeitfragen. 12/13. sept. 1998, No 211, p. 85.

68. Williamson, O. (1991). Comparative economic organizations: The analysis of discrete structural alternatives. Administrativ. 